\title{
Chapter 2 \\ Fundação Getulio Vargas' Efforts to Improve Basic Education Before, During, and After the Pandemic
}

\author{
Claudia Costin, João Lins, José Henrique Paim, Marieta de Moraes Ferreira, \\ Raquel de Oliveira, Teresa Pontual, and Vinicius Farias Santos
}

\begin{abstract}
This chapter details FGV's contributions to basic education during the pandemic. FGV created in 2003 an accessible tool that addresses the managerial gaps that schools and education departments face to evaluate and assess its students, called FGV High School. Since March 2020, when school closures took place, the rapid demand for digital education tools placed FGV High School in an advantageous position to establish partnerships with education departments across Brazil, benefiting millions of high school students. In the state of São Paulo alone, the FGV High School platform gives access to approximately 3.5 million students. In 2008, FGV became a member of Open Education Global (OEG), a consortium of educational institutions from different countries that provide online content and teaching materials free of charge. Since the beginning of the Covid-19 pandemic, the demand for FGV's online courses has substantially increased. In March 2020 alone, the program's website registered more than 1.6 million hits, and the number has since then consistently increased. Additionally, FGV has recently created two policy centers that focus on basic education: The Center for Excellence and Innovation in Education Policy (CEIPE), created in 2016, and the Center for the Development of Public Management and Educational Policy (DGPE), in 2018. Since the beginning of the pandemic, both centers have organized a series of webinars and publications to support policymakers in the education sector to make better decisions regarding reopening of schools, online and digital education options, curriculum, etc. The high number of views and engagement that the FGV webinars attract reflects the desire for reliable information that education professionals have been seeking, despite the overwhelming number of online events that have surfaced with the pandemic.
\end{abstract}

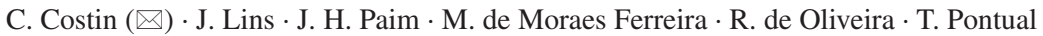

V. F. Santos

Fundacao Getulio Vargas, Sao Paulo, Brazil

e-mail: claudia.costin@fgv.br

(C) The Author(s) 2022

F. M. Reimers, F. J. Marmolejo (eds.), University and School Collaborations

during a Pandemic, Knowledge Studies in Higher Education 8,

https://doi.org/10.1007/978-3-030-82159-3_2 


\subsection{Introduction}

The Covid-19 pandemic reached Brazil in February, and its K-12 schools were closed by the end of March, leaving about 45 million students at home. As a result, Fundação Getulio Vargas (FGV), a Brazilian higher education institution and think tank, leveraged its resources to provide policymakers with access to reliable information to navigate the crisis, as well as access to high-quality, online educational resources for secondary students and education professionals.

The online resources directed at education professionals and secondary education students came from long-standing programs within the university and became integral for cities and states looking for readily and freely available remote learning strategies. The support offered to policymakers to address the Covid-19 crisis came primarily from two policy centers within FGV established in the last 4 years. Both centers are managed by leaders in Brazil's education policy landscape and dedicated to supporting basic education systems at the city and state levels. Because of their work prior to the pandemic, these centers had already developed close partnerships with departments of education in several cities and states. Also, the fact that FGV's Business and Public Administration School has such prominent names from the policy field in their faculty aligns with FGV's mission to stimulate Brazil's socioeconomic development. FGV sees itself as a change agent within Brazilian society, and by creating two centers focused on improving basic education, it recognizes that Brazil's socioeconomic development depends on equal educational opportunities for all.

This chapter provides in-depth details of FGV's contributions to education continuity during the pandemic. One of the unexpected results of the pandemic has been the increase in collaboration among the different centers and departments of FGV that focus on basic education, including the joint effort involved in preparing this chapter.

\subsection{About FGV}

Established in 1944 to promote Brazil's social and economic development, Fundação Getulio Vargas (FGV) has established itself as one of the top 10 think tanks in the world (according to the Global Go To Think Tank Index Report 2017) as well as a well-regarded higher education institution. Its vision is to be recognized as an innovative institution that is committed to Brazil's development, the formation of an academic elite, and the generation of public social goods.

FGV has ten different schools in areas such as Economics, Law, Public and Business Administration, Social Sciences, Applied Mathematics, Public Policy, and Government and over 90 research centers based in Rio de Janeiro, São Paulo, and Brasília. FGV also has two institutes, one of which offers executive education courses in over 100 cities. 
In 2019, FGV had 4919 undergraduate students, 2282 master's students, 463 PhD students, and 103,409 continuing education students. There were 606 master's dissertations and 85 doctoral theses approved. FGV's professors, researchers, and technicians produced 2460 academic papers and published 140 books. FGV executed 420 technical assistance projects and organized or co-organized 812 conferences and seminars. ${ }^{1}$

\subsection{FGV High School}

FGV's involvement in the discourse on basic education in Brazil dates to 1950, when it started Colégio Nova Friburgo, a school that implemented innovative education practices until its closing in 1977, due to financial and political circumstances. From 1971 until 1990, FGV ran the Institute for Advanced Studies in Education (IESAE), which promoted the discussion of a range of educational issues and offered post-graduate studies in Education. ${ }^{2}$ In keeping with this tradition, the initiative known as FGV High School ${ }^{3}$ was created in 2003 with the dual role of promoting a robust dialogue and impactful contributions to secondary education.

The FGV High School program's main objective is to establish partnerships with schools, departments of education, and other public and private institutions that work in providing or promoting secondary education. FGV High School also forges partnerships directly with teachers from public and private schools in the city of Rio de Janeiro to assist in the production of its pedagogical content.

Additionally, the program designs and produces teaching materials (from books to digital resources) and promotes debates - particularly through events, seminars, publications, etc. - that interrogate the most important issues and trends concerning secondary education. In the last 2 years, FGV High School published two books that compiled articles written by managers and specialists discussing contemporary challenges and best practices in secondary education: The Challenges of High School Education ${ }^{4}$ and The New high School Education and Itineraries Training Courses, ${ }^{5}$ issued in 2018 and 2020, respectively. Beyond accessible resources for teachers and school leaders, FGV has also produced digital tools for students.

Launched in 2012, the first version of FGV High School's online platform mainly targeted high school students who were studying for the National High School Examination (ENEM). ${ }^{6}$ Since then, the site has reached almost three million views

\footnotetext{
${ }^{1}$ FGV's 2019 Annual Report.

${ }^{2}$ Santos, P. S. M. B. dos. O Colégio Nova Friburgo da Fundação Getúlio Vargas: mergulhando em sua memória institucional. Rio de Janeiro, 2005.

${ }^{3}$ In Portuguese: FGV Ensino Médio.

${ }^{4}$ In Portuguese: Os Desafios do Ensino Médio, FGV Editora, 2018.

${ }^{5}$ In Portuguese: O Novo Ensino Médio e os Itinerários Formativos, FGV Editora, 2020.

${ }^{6}$ The National High School Examination (Exame Nacional do Ensino Médio - ENEM) is a yearly college entrance examination. Its results are used to access higher education in Brazilian public and private universities as well as some universities abroad.
} 
and more than 130,000 registered users. In 2019, the second version updated the platform with improvements to its functionalities and objectives.

The core strengths of FGV High School's online platform lie in the quality of production and constant review of content. After being used in the online platform and the ENEM model exams administered by FGV, the existing questions are regularly screened by various specialists in the areas covered (Languages, Natural and Social Sciences, and Mathematics) who analyze and propose improvements in terms of their form, content, and categorization criteria (such as skills and competencies).

Initially, students autonomously enrolled on the platform and would have access to digital resources and a question bank to take simple assessments. In the revised website, the program's focus shifted to provide the students with an evaluation platform that promotes dialogue between the student, the teacher, and the school. Furthermore, FGV High School also seeks constant feedback from teachers and students who use its services, regarding the quality and potential improvements of the online content and user experience.

FGV High School has signed agreements with public Departments of Education and private schools located in Rio de Janeiro and São Paulo. These partnerships comprise the development and monitoring of evaluation processes (mock tests) aligned with ENEM, emulating both the usual test conditions (physical exams) and the online environment (through the FGV High School online platform). Among its most successful and long-lasting partnerships are those made with the city of São Paulo's Department of Education and the SESC High School. ${ }^{7}$

\subsection{FGV High School's Response to the Pandemic}

Currently, the online initiative of the FGV High School has gained critical importance, especially considering the uncertainty surrounding the 2020 edition of ENEM that was finally set to January 2021, despite students' having expressed their preference for May 2021 on a Ministry of Education online survey. For the first time since the exam's creation, an online version of the test was administered to approximately 98,000 registered students (out of a total of 5,eight million ${ }^{8}$ ). Since FGV High School offers a tool that emulates the conditions of the virtual version of the exam, students who access for preparation are at an advantage.

\footnotetext{
${ }^{7}$ SESC High School is a full-time free residential high school located in Rio de Janeiro city which attends students from all over Brazil. The school was inaugurated in 2008 with 176 students. Nowadays, it serves 500 students. Their class size is limited to 15 students that range between 13 and 18 years old. SESC High School pedagogical project focuses on citizenship education and seeks to conciliate academic education with professional education. The school offers various types of educational activities and has a very extensive students' selection process.

85.8 million students registered to take the 2020 ENEM; 96 thousand will take the digital ENEM.
} 
Since March 2020, when measures of quarantines and school closures took place, the rapid demand for digital education tools placed FGV High School in an advantageous position to establish partnerships with education departments across Brazil, beyond the states of Rio de Janeiro and São Paulo. These new partnerships included agreements with the Departments of Education for the States of Bahia, Maranhão, and São Paulo. Given the expansion in geographic reach, millions of Brazilian high school students directly benefited from FGV High School's platform. In the state of São Paulo alone, the agreement gives access to approximately 3.5 million students.

Senior education leaders in Brazil are especially motivated to establish these beneficial partnerships because the public education system has previously lacked reliable online platforms that can assist teachers in the provision of exams and mock tests remotely. FGV High School program is particularly suited to fulfill this duty, since its platform creates, administers, and grades exams online, presenting a variety of data that allow teachers to understand each student's strengths as well as the gaps they need to address based on test performances. Accordingly, FGV High School's main role in the collective effort associated with non-tertiary education is primarily that of providing an accessible tool that addresses the managerial gaps schools and education departments face to evaluate and assess its students.

While the FGV High School platform has gained greater visibility and an expanded reach, some challenges have arisen from this sudden growth. These have ranged from having to manage a large and diversified portfolio of students, teachers, and schools to the necessity of continuous improvement of the platform's resources, which requires an effort to interpret the learning outcomes and aspirations of all users.

Nevertheless, the future of FGV High School lies in the maintenance and improvement of its tools and services. The importance of these materials and resources has only increased with the potential addition of millions of Brazilian students accessing them because of the pandemic. Hopefully, this program will endure beyond the pandemic and continue to help improve secondary education across Brazil.

\subsection{FGV Free Online Program}

In 2008, FGV was the first Brazilian institution to become a member of Open Education Global (OEG), a consortium of educational institutions from different countries that provide online content and teaching materials free of charge. Since the addition of the Free Online Course Program to FGV's education portfolio, the program has registered more than 13 million users and has issued approximately seven million certificates.

The courses available in the program are self-guided and encompass a variety of knowledge areas related to the fields of teaching and research within FGV's academic realms. Participants who satisfactorily complete a course may acquire a 
certificate. Currently the program offers 81 courses, with a course load varying between 8 and $30 \mathrm{~h}$; these courses all provide online education to diverse demographics such as vocational education students, undergraduate and graduate students, as well as established professionals who seek to update their skills and expand their competencies.

\subsection{FGV Free Online Program's Response to the Pandemic}

Since the beginning of the Covid-19 pandemic and the mandatory social isolation protocol adopted in Brazil, which included the closure of teaching facilities, the demand for FGV's online courses has substantially increased. In March 2020 alone, the program's website registered more than 1.6 million hits (accumulating over four million views) with these figures consistently increasing.

To adequately provide this service while facing a surge in its demand, FGV increased the program's investment by strengthening its technological infrastructure to ensure the high quality of user experience and expanding the program's offerings. From March to May 2020, 18 new courses became available, benefitting thousands of students.

During this period approximately one million students enrolled, and more than 300,000 certificates were issued. Graphs 2.1, 2.2, and 2.3 depict information concerning the program's numbers, specifically the monthly and accumulated enrollments from January to May 2020, as compared to the same period in 2019. Moreover, the compiled data shows that in comparison to the same period in 2019, the program's webpage views were multiplied by a factor of over 16 , while enrollments and completion certificates issued increased $233 \%$ and 136\%, respectively. Noticeably, all indicators detailed in the graphs below peaked in March, precisely

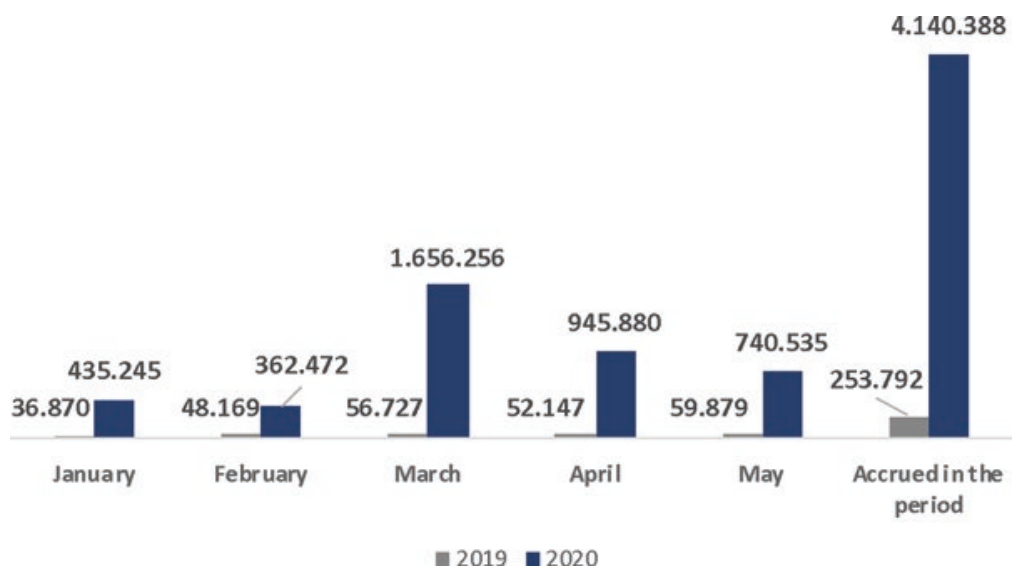

Graph 2.1 Access to the FGV Online Free Course Program's website (2020 vs. 2019). (Source: FGV Executive Education Department) 


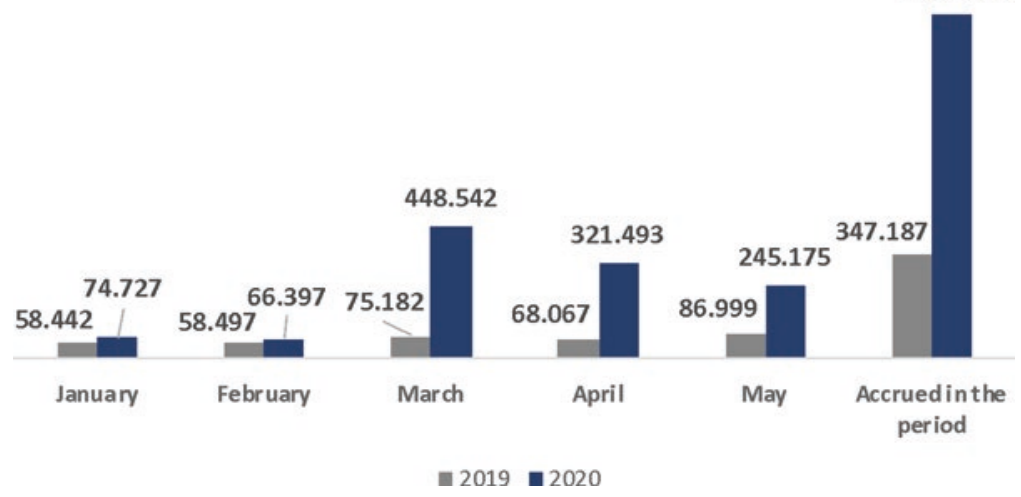

Graph 2.2 Enrollment in the FGV Online Free Course Program (2020 vs. 2019). (Source: FGV Executive Education Department)

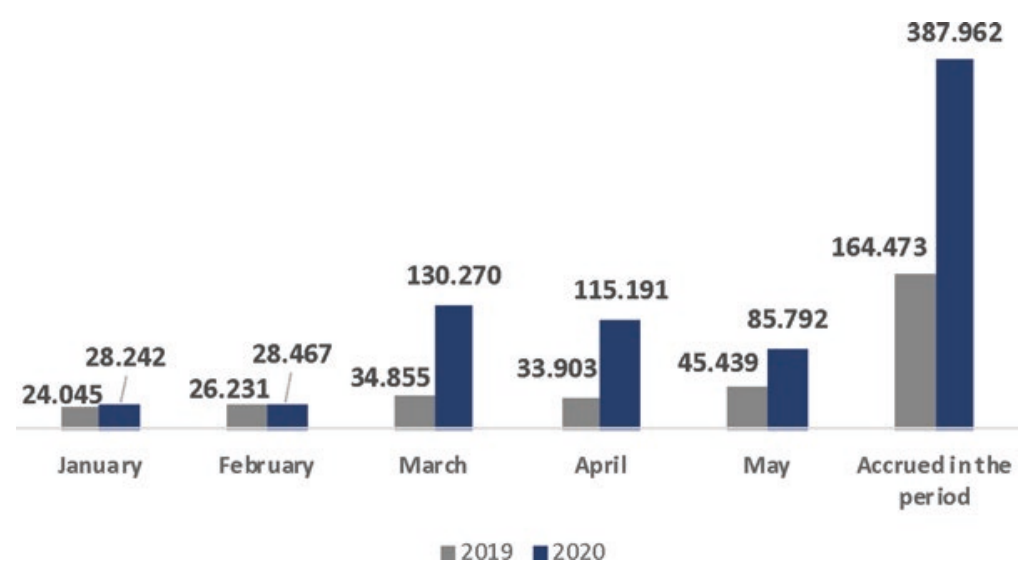

Graph 2.3 Statements of Completion issued in the FGV Online Free Course Program (2020 vs. 2019). (Source: FGV Executive Education Department)

the month in which the enforcement of measures regarding the Covid-19 pandemic started in Brazil.

Lately, FGV's Online Department has turned its efforts to promoting this program to an audience that works directly with public education in Brazil. By forging strategic partnerships with key actors, such as State Departments of Education, Consed $^{12}$ and Undime $^{14}$, the program was advertised and became known to a broader network of educational professionals (e.g., teachers, school principals, education system managers, etc.). The program also began developing specific content targeting the main topics related to the challenges faced by this audience in their roles.

FGV had formally signed agreements with some public Departments of Education, so that public sector education professionals and teachers of many state and municipalities in Brazil will be directly impacted by the program's 
communication and will be able to access this opportunity to invest in their own professional development, which will hopefully lead to improvements within Brazil's public education system.

\subsection{FGV's Policy Centers}

As previously mentioned, FGV recently created two policy centers which focus on basic education, which in Brazil means from Early Childhood Education to the end of High School. The Center for Excellence and Innovation in Education Policy $(\mathrm{CEIPE})^{9}$ was created in 2016 within the Brazilian School of Public and Business Administration (EBAPE) with the mission to improve educational policy management so that Brazil may have an equitable, innovative, and high-quality basic education. CEIPE offers technical assistance to city and state departments of education, produces policy briefs and other applied knowledge publications, and promotes leadership training. The Center for the Development of Public Management and Educational Policy (DGPE) ${ }^{10}$ was created in 2018 to promote the development of public management and support public teaching systems to improve education management.

Since late March 2020, both centers have focused on helping city and state Departments of Education from all regions in Brazil already supported by the Centers' projects adapt and respond to the challenges of the pandemic. To extend their reach beyond their current partnerships, both centers have organized a series of webinars featuring city and state education officials as well as representatives from national and international education NGOs to discuss policy responses and recommendations.

\subsection{Webinar Series}

To promote debates and spread knowledge on the challenges and potential solutions concerning educational issues during the pandemic, FGV hosted two webinars series with specialists and public officials at the forefront of educational policies tackling Covid-19 and its educational implications. The webinars have been open to the public to include all interested parties in such important discussions.

DGPE, FGV High School, and FGV In Company partnered with Consed and Itaú Social (the social responsibility arm of a Brazilian bank) to organize the series titled "Challenges of Basic Education in the Times of a Pandemic" on how to support educational systems in improving management during the Covid-19 crisis.

\footnotetext{
${ }^{9}$ In Portuguese: Centro de Excelência e Inovação em Políticas Educacionais.

${ }^{10}$ In Portuguese: Centro de Desenvolvimento da Gestão Pública e Políticas Educacionais.
} 
Considering the effort and dialogue with the state and municipal education networks, the series' objective was to achieve a joint definition of the optimal path to education continuity during the pandemic and possible ways to improve the planning and management of school reopening at this difficult time.

The expected outcome of these dialogues and debates is that new ideas emerge to illuminate and guide the path both state and municipal education departments could follow to mitigate issues and explore opportunities for innovative efforts within the context of this crisis. The Covid-19 pandemic accelerated the digital transformation of educational resources and signaled a renewed effort to improve the management of education across Brazil. To best facilitate these adjustments, this webinar series covered a wide range of relevant topics such as technology, teaching practices, pedagogical materials, logistical issues, and alternatives for monitoring and evaluating learning in the context of the pandemic crisis.

FGV selected and invited a diverse panel of experts with extensive experience in dealing with educational issues to guide these discussions. Among them were former Ministers of Education, governors, members of Brazil's National Education Council, state and municipal education secretaries, and members of Consed and Undime. Additionally, professors and representatives of international organizations, such as the United Nations Educational, Scientific and Cultural Organization (UNESCO), United Nations Children's Fund (UNICEF), Organization of IberoAmerican States (OEI), and Inter-American Development Bank (IDB), were involved as panelists.

Overall, DGPE's webinar series consisted of 12 webinars with more than 10,000 registered participants. CEIPE's webinar series entitled "Education Systems' Responses to the Pandemic" features state and municipal education systems that work diligently to keep students engaged and learning amidst school closures. The series' objective is to discuss and disseminate the experiences of various Departments of Education across Brazil that managed to implement alternative remote education solutions and face the educational challenges imposed by the pandemic. CEIPE's webinars brought together municipal and state secretaries of education whose remote learning strategies involved delivering lessons through several media (online platforms, mobile applications, television, radio) as well as delivering printed materials and providing sim cards with cellular data plans or sponsoring their remote learning mobile applications with the main telecommunications companies to reach all students. This exchange of experiences was meant to inspire all public education leaders to implement thoughtful strategies to ensure students were not excluded from learning opportunities while school buildings remained closed. A strength of this series was how it featured a wide range of municipal departments of education, from small rural cities to large capitals as well as state departments of education from all regions of Brazil, reflecting the wide variety of cultural and socioeconomic realities present across the country. Although national experiences were the primary recognized examples, CEIPE's staff consistently referenced international experiences in the dialogues and directed viewers to its Covid-19-related publications on 
their website. The high number of views and engagement that the FGV webinars attract reflects the desire for reliable information that policymakers and education professionals alike have been seeking, despite the overwhelming number of online events that have surfaced with the pandemic. CEIPE has also mentored 50 municipal and three state-level secretaries of education, to address the challenges created in their systems by the pandemic.

\subsection{Publications in the Context of Covid-19}

Among FGV CEIPE's many functions to fulfill its mission of improving educational policy management in Brazil, it produces and disseminates evidence-based knowledge to Brazilian policymakers and the public. As such, it has added Portuguese versions of publications related to the pandemic to its portfolio; for instance, CEIPE added four reports addressing the main challenges, best practices, and potential solutions to the issues brought upon education systems during the pandemic to its website.

The first such publication was the translation to Portuguese of "A Framework to Guide Education Response to the Covid-19 Pandemic of 2020" produced by Fernando Reimers and Andreas Schleicher and published by OECD, which addresses how efforts to continue education through alternate modalities should be directed while social distancing policies are necessarily enforced.

CEIPE has also translated the second report produced by Fernando Reimers and Andreas Schleicher: "Schooling Disrupted, Schooling Rethought: How the Covid-19 Pandemic is Changing Education." This research provides an insightful overview and recommendations based on the findings from a survey taken by departments of education in 59 countries on how their education systems have been affected by the pandemic and what measures they have employed in Covid-19's aftermath.

Additionally, "Managing Education Systems during Covid-19: An Open Letter to a Minister of Education" originally published by the Center for Global Development, which offers guidelines to education managers on how to better prepare for the implications the Covid-19 is bringing upon education, was added to the website, including a chapter from our founder and director, Claudia Costin.

More recently, FGV CEIPE translated the policy brief "Reopening Schools in the Context of Covid-19: Health and Safety Guidelines from Other Countries" originally published by the Learning Policy Institute, one of FGV CEIPE's partner institutions. This brief discusses preliminary information gathered from five countries that have already or were reopening their schools by the time of its publication.

Besides translated publications, FGV CEIPE also produced original content. Written by FGV CEIPE's Founder and Director, Claudia Costin, "Recommendations for Returning to Classes" provides a set of guidelines to assist departments of education in their strategies and implementation plans to reopen Brazilian schools. 
CEIPE will continue to produce its own materials to help Brazil's 26 states, the Federal District that hosts the country's capital, Brasilia, and 5568 municipal education systems face the challenges imposed by the pandemic as well as identify the best resources being produced worldwide and make them available to the Portuguesespeaking public.

\subsection{Conclusion: What Is Next?}

The variety of initiatives and centers engaged in meaningful work is evidence of FGV's long-standing and profound commitment to improve basic education in Brazil, which is closely aligned with its mission of contributing to the country's socioeconomic development. The pandemic has helped strengthen the reach and impact of several of FGV's online-based programs, such as FGV High School and its Free Online Program, given the general increase of interest in these types of digital solutions brought on by the school closures.

As the pandemic progresses, FGV will continue to provide guidance, information, and resources to public education leaders throughout Brazil. It is difficult to measure the impact of access to information on leaders' behavior and decisionmaking in general and that is no different in the current context. Nonetheless, FGV is helping shape the discussion, influencing policy decisions as well as how the media portrays the role of remote learning and the priority that should be given to safely reopening schools. This is evidenced by our specialists' constant media presence and their appearances on events alongside prominent public education decision-makers, such as National Education Council members, as well as Consed and Undime leaders. FGV is looked upon as a reliable, nonpartisan voice, amid polarized debate around sensitive issues such as inequalities in remote learning and the responsible reopening of schools during a pandemic. The webinars and publications produced provide pathways for Departments of Education which differ from the extreme viewpoints touted within the current political climate, based on what some departments of education have done to reach nearly all students with remote education and what other countries have been able to do to safely reopen schools.

Even if we can help leaders minimize the negative consequences of the pandemic, Brazil's Basic Education System, which was already among the poorest performers in PISA, is still likely to face even greater challenges in the post-Covid-19 era. Helping education systems worldwide rebuild better, more innovative structures for learning will require even greater efforts, more collaboration, and a wider array of stakeholders. As an institution at the cutting edge of academic knowledge and leadership training, FGV can play a prominent role in helping Brazil's Education System overcome this crisis with the tools to allow schools to function at the highest of standards. The greater integration between FGV's different programs and centers, such as those featured in this chapter, will be a legacy of this crisis. 


\section{References}

Fundação Getulio Vargas, 2019 Annual Report, 75th Edition.

G1- Globo News outlet media company. "Enem 2020 tem 5,8 milhões de inscritos confirmados; 96 mil farão prova digital", G1, 27 de junho de 2020. https://g1.globo.com/educacao/enem/2020/ noticia/2020/06/27/enem-2020-tem-58-milhoes-de-inscritos-confirmados-96-mil-farao-provadigital.ghtml. Accessed on 28 June 2020.

Santos, P. S. M. B. dos. (2005). O Colégio Nova Friburgo da Fundação Getúlio Vargas: mergulhando em sua memória institucional. Rio de Janeiro.

Claudia Costin is the Founder and Director of CEIPE - Center for Excellence and Innovation in Education Policies - a think-and-do tank located at FGV EBAPE, one of the most prestigious Public Administration and Business Schools in Brazil. She is a member of the Governing Board of Qatar Foundation and of UNESCO's Institute for Lifelong Learning - UIL. In the past, she was the Senior Director for Global Education in the World Bank. Prior to this, Claudia Costin was the Secretary of Education for the city of Rio de Janeiro, Brazil. Under her stewardship, learning results rose by 22 percent. Until 2009, she was the Vice-President of the Victor Civita Foundation, dedicated to raise the quality of public education in Brazil. Her former positions include being the Secretary of Culture of the state of São Paulo, Vice-minister and Minister of Public Administration and State Reform during Fernando Henrique Cardoso's presidency, and President of PromonIntelligens, a company focused on e-learning. She has also supported several African countries in public policy and State modernization. Claudia Costin is also a professor at FGV EBAPE. She has lectured at São Paulo's Pontifical Catholic University, Getulio Vargas Foundation, and INSPER Teaching and Research Institute. She was a visiting scholar at the École Nationale d'Administration Publique, Québec, and at the Harvard Graduate School of Education. She holds a master's degree in Economics from Getulio Vargas Foundation.

João Lins is Executive Director of FGV In Company. He holds a master's degree in Business Administration and is a PhD candidate (FGV Business Administration School of São Paulo). He was previously a partner at $\mathrm{PwC}$, leading the HR Consulting Practice in Brazil.

José Henrique Paim is the Founder and Director of FGV DGPE - Center for Public Management Development and Education Policies - a center located at Getulio Vargas Foundation (FGV), one of the most prestigious education institutions in Brazil. Previously, he worked as a consultant for the Inter-American Development Bank, the largest source of development financing for Latin America and the Caribbean. He has also been the Director of Brazil's National Bank for Economic and Social Development, where he was responsible for directing the Social, Farming, and Environmental sectors. In 2014, during Dilma Rousseff's presidency, he took office as Minister of Education. His career in the Ministry accounts for more than a decade. From 2006 to 2014, he held the post of Executive Secretary. Beforehand, he was the President of the National Fund for Education Development. His former positions include being the Special Undersecretary of Economic and Social Development Council for the President's Office and Secretary of Fundraising and International Cooperation for the city of Porto Alegre. He is a licensed professor at La Salle University and currently a professor at FGV EBAPE, Public Administration and Business School. José Henrique Paim holds a PhD in Education and Health Sciences and a master's degree in Economics from the Federal University of Rio Grande do Sul.

Marieta de Moraes Ferreira is a historian. She is a retired professor at the Federal University of Rio de Janeiro (UFRJ) and former researcher at UFRJ's Post-graduate Program in Social History. She has also been the Director of FGV CPDOC - Center for Research and Documentation of Contemporary History of Brazil - a center located at Getulio Vargas Foundation (FGV), where she had the opportunity to research, lecture, and to coordinate the Oral History Program. UFRJ and 
FGV are two of the most prestigious education institutions in Brazil. Until very recently, from 2013 to 2017, she was the National Coordinator of the Post-graduate Program in History Teaching. She was the Founder and first President of the Brazilian Oral History Association, having also presided the International Oral History Association. Currently, she is the Executive Director of Getulio Vargas Foundation (FGV) publishing house and the Coordinator of the FGV High School Program, which is focused on developing teaching materials. She dedicated her life to the study of the History of the Brazil's Republic, and she has undertaken research in numerous fields: History of Rio de Janeiro, Oral History, Present Time History, and Political History. She is the author of "History as an Occupation - The Constitution of a Disciplinary Field" (2013) and "Uses and Abuses of Oral History" (1996), among other works. She is also the co-author of "Present Time History," published in 2014. She holds a PhD in History from the Fluminense Federal University and Post-doctorate degrees from École des Hautes en Sciences Sociales and from the University of São Paulo.

Raquel de Oliveira works as a project manager at the Center for Excellence and Innovation in Educational Policies within the Brazilian School of Public and Business Administration of the Getúlio Vargas Foundation. She is also part of the British Startup Gigalime during the Covid-19 crisis, which aims to rethink possible futures and spaces for digital transformation so that educational systems are redesigned to address the growing needs of contemporary societies. She teaches in the Postgraduate Course of the Singularidades Institute the discipline Methodologies and Teaching Practices. She was Pearson Fellow, within the Master of Public Policy (MPP) program at The Pearson Institute for the Study and Resolution of Global Conflicts, working with early childhood in daycare centers in South Africa. She attended "Excellence in Basic Education Course The Experience of Shanghai" at Shanghai Normal University, an institution responsible for the initial and continuing training of public-school teachers in Shanghai.

Teresa Pontual is the Executive Manager at CEIPE - Center for Excellence and Innovation in Education Policies - a think-and-do tank located at FGV EBAPE. Before taking office, she was the Director of Curriculum at the Ministry of Education. Prior to this, Teresa Pontual was the Undersecretary of Education at the Department of Education for the city of Salvador. Teresa also worked as Project Manager at the Department of Education for the city of Rio and Undersecretary of Education at the Department of Education for the state of Rio de Janeiro. Teresa Pontual holds a master's degree in International Education Policy from the Harvard Graduate School of Education, where she was awarded a Lemann Fellowship, an MBA from the Federal University of Rio de Janeiro, and a bachelor's degree in Political Science from Swarthmore College, in Pennsylvania.

Vinicius Farias Santos is Executive manager of FGV In Company. He holds a master's degree in Business Administration and an MBA in Business Management from FGV EBAPE - Brazilian School of Public and Business Management. He is a public-school teacher and former member of the Educational Technology Management team at Rio de Janeiro's City Department of Education.

Open Access This chapter is licensed under the terms of the Creative Commons Attribution 4.0 International License (http://creativecommons.org/licenses/by/4.0/), which permits use, sharing, adaptation, distribution and reproduction in any medium or format, as long as you give appropriate credit to the original author(s) and the source, provide a link to the Creative Commons license and indicate if changes were made.

The images or other third party material in this chapter are included in the chapter's Creative Commons license, unless indicated otherwise in a credit line to the material. If material is not included in the chapter's Creative Commons license and your intended use is not permitted by statutory regulation or exceeds the permitted use, you will need to obtain permission directly from the copyright holder. 